\title{
PREVENTIVE MEASURES OF INFRASTRUCTURES
}

\author{
Lajos $S Z A B O^{*}$ \\ Zsuzsanna BALOGH, PhD**
}

The infrastructure elements are often recognized when their continuity stops, although their security is a topic that is often concerning only their cyber protection, not the physical one. There are many examples in the world where the prevention of infrastructure is taken seriously and handled properly. These recommendations and guidance could be easily adapted anywhere. The aim of this paper is to show some of the existing ways, tools, and techniques of protecting (critical) infrastructure elements that can be easily adapted in Hungary. Based on these foreign regulations the Hungarian legislative system could create a national one with the support of the decision makers.

Keywords: security; defence; regulations; measure; prevention.

\section{Introduction}

This special field of facilities protection is the application of security systems in the surrounding private and public areas, which ensures the prevention of different kind of incidents and extraordinary events effecting the facility, using mechanical, technical (electronic), as well as security guards and organizing methods.

The field of preventive defence is a vital part of organizing the zones of the facility protection. Its objective with respect to the facility is detecting, identifying, preventing the evolution of, or impeding the irregularities originating from environment risks that lead to extraordinary events. If all the above are unfeasible it will send an alert,

* Lieutenant Colonel (police) Lajos SZABÓ is PhD candidate at Obudai University in Budapest, Hungary.E-mail: szabo.lajos@bgk.uni-obuda.hu ** Lieutenant Colonel Zsuzsanna BALOGH, PhD, is a Professor within the Doctoral School of Military Engineering of National University of Public Service, Budapest, Hungary.E-mail: balogh.zsuzsanna@uni-nke.hu 
react according to protocol, and decrease the effects of the consequences.

Preventive measures - similarly to other aspects of facility defence - can be broken down into more zones. Protecting defence ensures the integration of the area, as well as the safety and health of the people who work there. The data resulting from their work, the assets used for the activity remain intact along with the flow of the process itself of a given establishment, against human actions or environmental changes, at a degree which has been predetermined during risk assessment.

The level of protection shall be interpreted as the solutions based on the assessment and identification of risks, which are results that have been accurately calculated from the degree of the expected danger. As well as an action that threatens with an explosion, it is isolated from its surroundings, so the effects of even the most powerful detonation possible can be decreased to a level that is environmentally responsible.

As well as a barrier lowers the maximum velocity of an approaching vehicle to an adequate speed or stops a transport of a predetermined weight, size, and velocity or simply detects an object with predetermined weight, size, velocity, and direction at a given distance, then signals to the guards, that can be deployed in time with the numbers and equipment necessary to perform a task.

After threats have been received in the identifying and alerting zones, evacuation, if applicable, or the process of finding cover can be initiated, while additional troops can be deployed in the other areas ${ }^{1}$. The process is the same when it is necessary to eliminate the possibility for an individual or individuals, to perform an unlawful act that effects the facility. In order to assure that the equipment applied indeed meets the above-mentioned criteria, standardized mechanical and electronic tools are needed, that are proven to be inspected with respect to predetermined parameters.

For the security forces and other organizational solutions, there must be some regulations, administrative measures agreed upon with the facility managements.

\section{Proven Practices in Preventive Defence}

In Hungary it is generally out of the ordinary to consider such measures in case of public and private facilities. The exceptions are overly conspicuous solely to the experts, for instance, the Kossuth Square in Budapest, where a system of multiple zones of security force is in use around the Parliament building, but this is a unique exception.

Unfortunately, there are no Hungarian standards, which would require the

${ }^{1}$ Prof. Dr. Lukács László, Dr. Balogh Zsuzsanna "Bombatámadás az USA nagykövetség ellen Nairobi, 1998. augusztus 07.” Müszaki Katonai Közlöny, no.23/2013, vol. 2, URL: https://mkk.uninke.hu/document/mkk-uni-nke-hu/2013_2_13_Nairobi.pdf 
design and installation of such systems. In the Acts that regulates building norms, a chapter on how to gain building permit does not exist ${ }^{2}$. Since it is not required by law, nor is it regulated in any form of city planning, it does not demand investors and designers to comply or even pay any attention and take these issues into consideration. Therefore, these "flawed" designs of "unprotected" buildings are constructed one after another.

The experience is the same with architecture, accounting, security, lifestyle, and health recommendations - even though they are scientifically proven not to be harmful, in fact quite the opposite, there is no threat of sanctions to those responsible, when ignored.

In the following, already proven practices and tested, standardized solutions are presented as examples, applicable for facilities, events and venues when ensuring their preventive defence.

\subsection{Administrative tools}

The regulations here are such complex recommendations for construction and architecture that are applicable in any settlement of the world and contain a complete list of solutions for the threat at hand.

\section{EN-14383 Prevention of crime - Urban planning and building design}

These series of standards published in 2006 consist of several sections, out of which only the first one, dealing with technical terms and definitions, was translated to Hungarian, but not completely. This chapter of the European Standard represents the terminology part of a series for the "Prevention of crime by urban planning and building design" 3 .

There would have been other advantages besides being part of the fight against terrorism, but it has not been implemented for over 15 years, even though attacks other than ramming have occurred in Europe in recent years, against which only improvised concrete obstacles and planters were utilized. The fact is, this standard is not translated into Hungarian (only the preface is translated) and it is not in use.

\footnotetext{
2***, 253/1997 (XII. 20) Korm. rendelet az országos településrendezési és építési követelményekről URL: https://net.jogtar.hu/jogszabaly?docid=99700253.kor

${ }^{3}$ Magyar Szabvanyugyi Testulet, MSZ EN 14383-1, 2006, Bünmegelőzés, Településrendezés és épülettervezés, part 1, Szakkifejezések URL: http:/www.mszt.hu/web/guest/webaruhaz?p_p_ $\mathrm{id}=\mathrm{msztwebshop}$ _WAR_MsztWAportlet\&p_p_lifecycle $=1 \& \mathrm{p} \_p \_s t a t e=$ normal\&p_p_ mode $=$ view\&p_p_col_id $=$ column-1\&p_p_col_pos $=1 \& p \_p \_c o l \_c o u n t=2 \& \_m s z t w e b s h o p \_W A R \_$ MsztWAportlet_ref $=1 \overline{4} 1837 \&$ msztwebshop_WAR_MsztWÄportlet_javax.portlet.action=search
} 


\section{UFC 4-010-01 9 February 2012 Unified Facilities Criteria (UFC) DoD Minimum Antiterrorism Standards for Buildings ${ }^{4}$}

This standard developed by the Department of Defense of the United States of America is mandatory, not only on US territory, in the design of every installation, in order to reduce their vulnerability in case of terrorist attacks (mainly conducted with explosives). It contains a detailed list of scaled minimal and higher security level regulations for new, old, owned, and leased buildings. It gives examples for residential, business, and social functions as well. Besides the basic functions of the area, it contains a useful set of solutions for any other perceived threat.

There are other guides and standards such as Certification Standard Forced Entry And Ballistic Resistance Of Structural Systems ${ }^{5}$ or the Guide to Active Vehicle Barrier (AVB) Specification and Selection Resources ${ }^{6}$, but they are not the subject of this paper.

Though it is obvious that thorough, specific regulations containing a very serious amount of content, which increases people's safety, are necessary for constructing public buildings or other facilities suitable for housing large masses. The importance of the problem has been admitted all over the world; for example, in 2004 a publication was created as part of the strategy of National Security of Singapore, which describes the possibilities of the strengthening of buildings against terrorist attacks. Within this, in 2004 the city of Singapore has published a brochure ${ }^{7}$ titled Guidelines for enhancing building security in Singapore, then organized a conference to discuss its findings.

Australia did not waste much time, they issued the "Urban Design Guidelines for Perimeter Security in the National Capital", based on which at least the public areas and buildings of the capital city were designed ${ }^{8}$.

\footnotetext{
${ }^{4}$ Department of Defense, Unified Facilities Criteria (UFC) DoD Minimum Antiterrorism Standards for Buildings, 2012, URL: https://www.wbdg.org/FFC/DOD/UFC/ARCHIVES/ufc_4_010_01_2012.pdf 5 Certification Standard Forced Entry And Ballistic Resistance Of Structural Systems, U.S. State Department, Washington D.C., 1993, URL: https://www.shieldsecuritydoors.com/ uploads/2/7/3/6/27366561/sd-std-01-01.pdf

${ }_{6}$ Cybersecurity and Infrastructure Security Agency, Guide to Active Vehicle Barrier (AVB) Specification and Selection Resources, 1995, URL: https:/www.cisa.gov/sites/default/files/ publications/Guide-to-Active-Vehicle-Barrier-2014-508.pdf

${ }^{7}$ Guidelines for Enhancing Building Security in Singapore, Joint Operations Group - Ministry of Home Affairs, Singapore URL: https:/www.bca.gov.sg/publications/BuildingSecurity/others/bldg_ security_guide.pdf

${ }^{8}$ Urban Design Guidelines for Perimeter Security in the National Capital, National Capital Authority, URL: https://www.nca.gov.au/planning-heritage/strategic-planning/guidelines-development/ guidelines-perimeter-security-national
} 


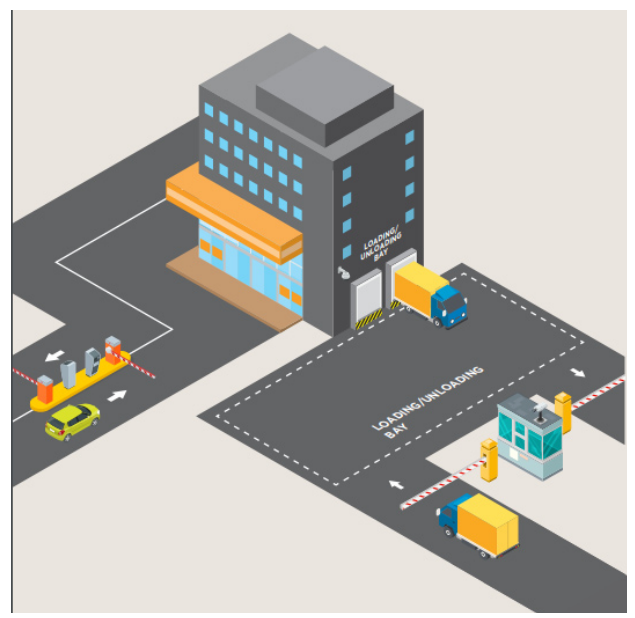

Figure no. 1: Design of Delivery/ Service Vehicle Access Control ${ }^{9}$

The commonalities of the mentioned recommendations and regulations are:

a) The demarcation of roads from buildings using safe distances;

b) These demarcations shall be done using dimensioned and built elements, street furniture;

c) Application of level shifting and green areas;

d) Breaking up the straightness of the road making it impossible to speed up;

e) The protection of the ground level and entrances of the buildings against attacks carried out with vehicles;

f) Creating safe escape routes and areas when designing the buildings;

g) Use standardized equipment.

\subsection{Mechanical obstacles}

\section{Sand or gravel}

Sand and gravel have been applied in motorsports for decades to improve the safety of the run-off area. They are designed with precision in accordance with the vehicle's dimensions and velocity, while its purpose is decelerating, halting, or decreasing the force of the impact of the vehicle. It would not require much to create and establish such flower beds and grassy areas, that have such incompact ground that an oncoming vehicle would beach in it.

Tall, strong but unattractive concrete, metal or other obstacles that might not fit into the view are unnecessary. Creating parks and taking care of them continuously is adequate, for which the purpose is not only to nurture the plants, but also making sure the ground is loose enough to perform its task.

\footnotetext{
${ }_{9}^{9}$ Joint Operations Group - Ministry of Home Affairs, Guidelines for enhancing building security in Singapore, p. 88.
} 


\section{Hidden ditches}

In November 17, 2017, in Györ, while installing the Christmas tree of the city, a truck was accidentally driven over an area of the square beneath of which the pipes of the fountain were located and covered. This pipe system was designed to bear the weight of pedestrians and light vehicles - such as bicycles, strollers and wheelchairs - along with their passengers but it immediately collapsed under the weight of a truck, and it was only possible to rescue it with a special crane.

Utilizing such unwanted experiences, urban planners can take further steps in creating a more secure environment. Hidden ditches of this kind shall be placed underneath the pavement of the square, naturally after careful planning and testing, that are aesthetic, fully perform the role of a sidewalk and public space, but on the other hand are able to perform as road obstacles.

\section{Obstacles slowing traffic flow}

In Hungary, every municipality can install speed bumps however they wish. The fact that these bumps in the everyday life can cause serious accidents, if damaged by any degree or are invisible without proper street lighting, is known by every motorist or cyclist. The goal, namely decreasing the speed of vehicles, can be achieved by alternate methods. In several Western European small towns for instance, small bays are created on alternating sides of the road to decrease the free cross section, in which massive poles equipped with reflecting lights are placed. The vehicles are efficiently decelerated by this slalom since it forces the drivers manoeuvres constantly and pay attention to oncoming traffic. Now only planters with large trees are present, which unfortunately blocks a large portion of the view of the road, and the obstacles that may be behind it, such as a pedestrian attempting to cross the road or a road worker, they can only be noticed once the vehicle is aligned with them.

The slalom system mentioned above is safer in terms of traffic technology, and the pole placed in them may serve as obstacles as well if placed adequately.

Numerous firms possess built in or mobile equipment, technologies that are tested and comply with the standards, with which the temporary or permanent regulation or obstruction of traffic is possible. These are displayed at the annual Security \& Counter Terror Expo in London, and other similar themed exhibitions in Europe by these companies and retailers.

Several solutions are available that are not installed with demonstrative deterrent intention but are totally integrated into the environment. They are disguised as curb, bench, trash container, lamp post or a bus stop and are fully capable of performing their original function. Besides their pleasant appearance, they are also high efficiency barriers, that protect the ones located behind them, even against the impact of a truck weighing several tons. These - so-called street furniture - are aesthetic and are available in a variety of materials and colours. 


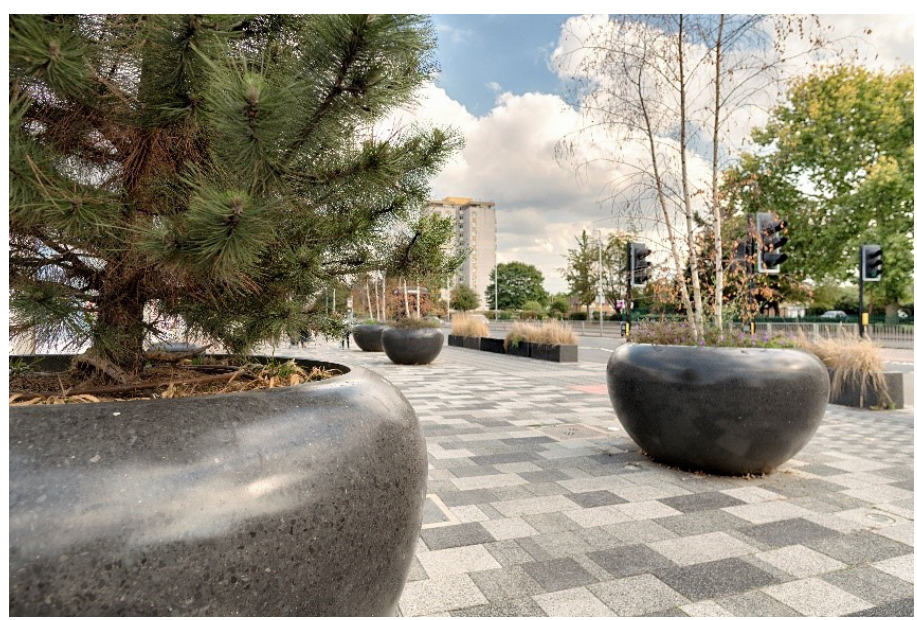

Figure no. 2: Planters ${ }^{10}$

Obviously, a planter that some cases exceed a meter in height, weighing up to a ton including the plants and soil, can seem like a safe barrier at first glance. Unfortunately, it only appears so, since if it does not possess adequate stability, was never tested for collisions, it can potentially increase the threat to its environment by capsizing or disintegrating. The displaced debris or moving, uncontrollably drifting large object can kill or injure anyone. The truly effective solution is the exclusive application of dimensioned, tested, and proven equipment that were made suitable for their task by inspected and compliant installation and construction.

The applied impact test standards basically work on the same basis - detailing the method and means of measuring the performance outcome for impact tested vehicle security barriers. IWA stands for 'International Workshop Agreement' and is overseen by the International Organization for Standardization (ISO). For example, the IWA $14.1^{11}$ - has a larger number of vehicle categories than either PAS 68 or ASTM with a total of nine types of vehicles. The IWA 14-2 ${ }^{12}: 2013$ provides guidance for the selection, installation and use of vehicle security barriers (VSBs) and describes the process of producing operational requirements (ORs). $\mathrm{BSi}^{13} \mathrm{PAS}^{14}$ 68:2013 - It has become the UK's standard and the security industry's benchmark

\footnotetext{
${ }^{10}$ Source: URL: https://www.marshalls.co.uk/commercial/product/giove-planter\#image-carousel-3

${ }^{11}$ Frontier Pitts, IWA 141, URL: http://www.frontierpitts.com/support-documentation/standards/ iwa-141/

${ }_{12}$ Frontier Pitts, IWA-142, URL: http://www.frontierpitts.com/support-documentation/standards/ iwa-142/

${ }_{13}$ Frontier Pitts, BSI-PAS-68, 2013, URL: http://www.frontierpitts.com/support-documentation/ standards/bsi-pas-682013/

${ }_{14}$ Frontier Pitts, CWA-16221 http://www.frontierpitts.com/support-documentation/standards/cwa$16221 /$
} 
for HVM (Hostile Vehicle Mitigation) equipment and is the specification against which perimeter security equipment is tested as part of the ongoing research to prevent VBIED (Vehicle Born Improvised Explosive Device) attacks.

CWA 16221: $2010^{15}$ Vehicle security barriers. Performance requirements, test methods and guidance on application. A European CEN workshop agreement that combines the detail from BSI PAS $68^{16}$ and PAS $69^{17}$. It provides guidance on test methods for determining vehicle security barrier performance classification and also includes a series of informative annexes that advise on appropriate product selection, installation and use.

The ASTM F2656-0718, Standard Test Method for Vehicle Crash Testing of Perimeter Barriers rates barriers in twelve impact categories, with three predetermined impact velocities for each category and four potential penetration ratings for each impact rating.

\section{Applicable Electrotechnical Equipment}

The variety of the variability and mechanism of effectivity of this equipment is so large, that their applications will only be mentioned in a listed form.

Streetlights - that can disperse light, or reflectors equipped with motion sensors. Spaces entirely lit up, where CCTV ${ }^{19}$ is in operation in cases as well, are not popular amongst perpetrators. Motion sensor reflectors also create a strong "stop feeling" on individuals effected by the strong, blinding light.

Motion sensor systems - that can be placed anywhere around the protected facility, even in front of the fence or wall. Optimally, the elements and street furniture surrounding the protected facility can be equipped by such defence, e.g. the streetlights being triggered via motion sensors in case of any movement or the space is lit up by more intense light, it can have enough psychological effect on any individual not trying to stand out.

Cameras - Nowadays wide scoped monitoring of public spaces via cameras are totally accepted, which can be developed into a much more effective equipment, more than just a regular monitoring system using various software. These are

\footnotetext{
${ }^{15}$ Edward Roberts, "What is PAS 68? The Definitive Guide to PAS 68", ATG Access, URL: https:// www.atgaccess.com/news/guides/what-is-pas-68

${ }^{16}$ Frontier Pitts, PAS 68, URL: https://www.frontierpitts.com/products/gates/hvm-gates/pas68-terraswing/

${ }^{17}$ Frontier Pitts, PAS 69, URL: https://www.frontierpitts.com/about-frontier-pitts/standards/bsi-pas692013/

18 ASTM International, Standard Test Method for Vehicle Crash Testing of Perimeter Barriers rates barriers, West Conshohocken, 2007, URL: https://webstore.ansi.org/Standards/ASTM/ ASTMF265607

${ }^{19}$ A.N.: closed-circuit television.
} 
programs capable of monitoring abandoned objects, recognizing of faces and body types or even unique movements and walking styles. These can be utilized for the purpose of crime prevention or investigation at any given time, similar to certain Chinese police squads that have been equipped with glasses running on such systems.

As much as the regulations regarding protection of personal data the cameras monitoring public spaces is an obstacle, in terms of CCTV systems, the problem is manageable within the boundaries of personal data protection actions. It is enough to install the fence or wall one or two meters from the border above the private property, it can be monitored via cameras, assuming it is positioned correctly, with the placement of warning signs and pictograms according to regulations. In the same manner the entrance, be it pedestrian or vehicle, can be placed at such an angle that anyone attempting to enter is already within the borders of the property and, therefore, they can be monitored.

The electrical equipment within security engineering can be applied to install such camera systems that when paired with other sensors and supported by software are capable of detecting a vehicle on land, sea or air, exceeding a given dimension or speed or an individual arriving with suspicious items but also to give out alerts.

This way, in case of hazardous vehicles or personnel the local security forces can be alerted and evacuation can be attempted. Furthermore, the system can arm passive mechanical equipment, for instance in case of a vehicle, the hidden poles can be raised from the road surface and hence obstructing the possibility of reaching further or it can illuminate and blind any individual within a dangerous proximity.

Naturally, this also requires regulation and design the same as the the application of every single security engineering device.

\section{Applicable Live Force}

Within the area of preventive defence, a multi-level zone of guards is created with respect to its own zone.

The application of live force can be in an open, intimidating manner using uniforms that clearly display the weapons and enforcement equipment. With a similar demonstrative intention, guards in civilian attire can be deployed covering their aforementioned equipment. In a given case, if there is ever a need for it as seen by anyone entitled, the screening or quick reaction on-the-spot in each zone can be presented by guards that are hidden or placed in a conspirative manner.

The personnel of several armed forces, be it police, civilian, body- or security guards, can be present in the area simultaneously, either in cooperation or operating separately. That provides a large flexibility within the application of live forces. 


\section{Conclusion}

There are many possible ways to improve the current situation. The first and most important step could be the creation of a strategic regulation or recommendation, which clarifies on what principle and for the handling of what risks it was created, to whom it is addressed, what are their responsibilities, and what recommendations or compulsory regulations are prescribed to manage them. The addressees could be national agencies, the owner/operator of the critical infrastructure, county or city councils, public institutions, and proprietors or management of businesses that conduct public service or has a specific area/capacity. The Directives only "wishes" the point is what the states are implemented. For example, in Hungary only the nuclear industry we have a Government Regulation from physical protection.

This would be followed by the second level, the addressees conducting standard creation and norm constitution, in which the preparation of detailed plans for private properties open for public use or public spaces bordered by private properties can be recommended or regulated. The sanction and inspection system could appear here as well, which would ensure that the strategic level decisions formulated materialize.

The third stage would be the documentation, planning, implementation, operation, and maintenance performed in terms of public spaces and private properties.

In summary, the easiest way to handle the problem is with administrative tools. Recommendations of any number and quality can be provided but until it is not mandatory to apply, design and fund they will be ignored, primarily for cost reduction purposes. It is time that, according to the listed standards in this study, steps are taken to create normative regulations in Hungary as well. The security awareness of people should be raised and leadership in decision making position should own these goals to reach.

\section{BIBLIOGRAPHY:}

1. ***, 190/2011 (IX 19) Korm. rendelet az atomenergia alkalmazása körében a fizikai védelemről és a kapcsolódó engedélyezési, jelentési és ellenőrzési rendszerről, URL: https://net.jogtar.hu/jogszabaly?docid=a1100190.kor

2. ***, 253/1997, (XII 20), Korm. rendelet az országos településrendezési és építési követelményekröl, URL: https://net.jogtar.hu/jogszabaly?docid=99700253.kor

3. ***, BSI-PAS-68, Frontier Pitts, 2013, URL: http://www.frontierpitts.com/ support-documentation/standards/bsi-pas-682013/

4. ***, Certification Standard Forced Entry And Ballistic Resistance Of Structural Systems, U.S. State Department, Washington D.C., 1993, URL: https:// www.shieldsecuritydoors.com/uploads/2/7/3/6/27366561/sd-std-01-01.pdf 
5. ***, CWA-16221, Frontier Pitts, URL: http://www.frontierpitts.com/supportdocumentation/standards/cwa-16221/

6. ***, Guide to Active Vehicle Barrier (AVB) Specification and Selection Resources, Cybersecurity and Infrastructure Security Agency, 1995, URL: https:// www.cisa.gov/sites/default/files/publications/Guide-to-Active-Vehicle-Barrier2014-508.pdf

7. ***, Guidelines for Enhancing Building Security in Singapore, Joint Operations Group, Ministry of Home Affairs, Singapore, URL: https://www.bca. gov.sg/publications/BuildingSecurity/others/bldg_security_guide.pdf

8. ***,IWA 141, Frontier Pitts, URL: http://www.frontierpitts.com/supportdocumentation/standards/iwa-141/

9. ***, IWA-142, Frontier Pitts, URL: http://www.frontierpitts.com/supportdocumentation/standards/iwa-142/

10. ***,MSZEN 14383-1:2006, Magyar Szabvanyugyi Testulet, Bünmegelőzés. Településrendezés és épülettervezés, Szakkifejezések, part 1, URL: http://www.mszt. $\mathrm{hu} / \mathrm{web} /$ guest/webaruhaz?p_p_id=msztwebshop_WAR_MsztWAportlet\&p_p_ lifecycle $=1 \& p \_p \_s t a t e=$ normal\&p_p_mode $=$ view\&p_p_col_id $=$ column-

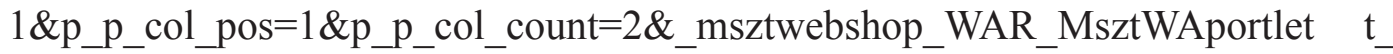
ref $=141837 \&$ msztwebshop_WAR_MsztWAportlet_javax.portlet.action=search

11. ***, PAS 68, Frontier Pitts, URL: https://www.frontierpitts.com/products/ gates/hvm-gates/pas68-terra-swing/

12. ***, PAS 69, Frontier Pitts, URL: https://www.frontierpitts.com/aboutfrontier-pitts/standards/bsi-pas-692013/

13. ***, Standard Test Method for Vehicle Crash Testing of Perimeter Barriers rates barriers, West Conshohocken, ASTM International, 2007, URL: https:// webstore.ansi.org/Standards/ASTM/ASTMF265607

14. ***, Unified Facilities Criteria (UFC) DoD Minimum Antiterrorism Standards for Buildings, Department of Defense, 2012, URL: https://www.wbdg. org/FFC/DOD/UFC/ARCHIVES/ufc_4_010_01_2012.pdf

15. ***, Urban Design Guidelines for Perimeter Security in the National Capital, National Capital Authority, URL: https://www.nca.gov.au/planningheritage/strategic-planning/guidelines-development/guidelines-perimeter-securitynational

16. LÁSZLÓ, Lukács; BALOGH, Zsuzsanna "Bombatámadás az USA nagykövetség ellen - Nairobi, 1998. augusztus 07”, Müszaki Katonai Közlöny, no. 23/2013, vol. 2, URL: https://mkk.uni-nke.hu/document/mkk-uni-nkehu/2013_2_13_Nairobi.pdf

17. ROBERTS, Edward, "What is PAS 68? The Definitive Guide to PAS 68", ATG Access, URL: https://www.atgaccess.com/news/guides/what-is-pas-68 